\title{
Designing of Basic Chemistry Course to Support Learning Curriculum with Green Chemistry Insight
}

\author{
Mitarlis, Utiya Azizah, and Bertha Yonata \\ Department of Chemistry \\ Universitas Negeri Surabaya \\ Surabaya, Indonesia \\ mitarlis@unesa.ac.id, utiyaazizah@unesa.ac.id, berthayonata@unesa.ac.id
}

\begin{abstract}
This article presents the results of study in a series of development of learning materials with green chemistry insight. The issues that will be discussed in this paper are describe the feasibility of basic chemistry course design to support learning curriculum with green chemistry insight and its supporting learning materials. The principle method used consists of three stages: preliminary study supported by reference study, development, and the evaluation by the expert. Reference study had been done by mapping the concept or principles of green chemistry related to curriculum design of basic chemistry course that presented in the Semester Learning Plan (SLP). This stage identify the appearance of green chemistry principles in learning. Development stage had been done by designing learning experience with green chemistry insight for student that presented on SLP and Lesson Plan (LP). Evaluation by the expert to get feasibility of learning design using validation sheet. The results showed that; the feasibility of curriculum design of basic chemistry course with green chemistry insight is very feasible. The principle of green chemistry can be raised as an insight both for classroom and laboratory activities. Learning experiences for classroom learning appear related to the students' behavior or character and practicum activities in the laboratory can be given green chemistry insight. Feasibility of learning device like student worksheet both of theoretical and practice on very feasible category. Among of 12 principles of green chemistry, several principles that can be raised in the basic chemistry learning were (1) prevent or reduce the formation of waste principle that can be raised through the learning experience in the form of practical activities such as on the separated mixture by distillation process;(2) energy efficiency principle and principle of waste prevention or reduce; and (3) creating safer conditions and preventing accidents principle that can be generated in laboratory activities on almost all topics. It is suggested that the principles of green chemistry are possible to integrate in the other curriculum of learning.
\end{abstract}

Keywords - green chemistry insight; curriculum design; learning experience

\section{INTRODUCTION}

Environmental aspects become one of the basic references in every development process today. Environmental issues as an important issue and need attention in local, national, and even global contexts. College is a place where educated people are educated and matured in order to provide solutions in a nation's problems. The level of progress of a country can be seen from the quality of college. Therefore, it should be a university to spearhead the forefront in solving a nation's problems, including environmental problems. Learning related to environmental issues can actually be integrated in each course.

Basic Chemistry course as a branch of science and its practical activities, is very likely to implement environmental education in order to realize Green Education. In the implementation of the process of learning in the classroom or in the laboratory has actually been inserted the values of the characters, especially those with green chemistry insight that sometimes we do not realize it. Green Chemistry is a philosophy or concept that encourages the design of a product or process that reduces or eliminates the use and income of harmful substances [1].

This philosophy is translated into the principles of green chemistry. Anastas (2008) formulated 12 items the principle of green chemistry successfully [2]. The 12 principles of green chemistry are; 1) Waste prevention, 2) Atomic economy, 3) Less hazardous chemical synthesis design, 4) Designing safer chemicals, 5) Use safer solvent and auxiliaries, 6) Design for energy efficiency, 7) Use of renewable feedstock, 8) Reduce derivatives, 9) Catalysis, 10) Design for degradation, 11) Realtime analysis for pollution prevention, 12) Inherently benign chemistry for accident prevention. Several of these principles can be applied in the field of chemistry or chemical industries, and tried to be applied in learning. Therefore, it is necessary to design a curriculum with green chemistry insight, especially for basic chemistry subject that programmed by pre-service teacher students. This is supported by the results of research on the views of prospective teacher candidates on the environment after they attended Green Chemistry lectures, which showed an increase in eco-centric attitudes and reduced their homo-centric and egocentric attitudes [3].

Research on environmental education is motivated by the understanding that the effects of environmental change do not 
only occur in pre-knowledge and attitudes but also on associations and are determined by self-motivation. The study was conducted by designing a test of the motivation change hypothesis on the green chemistry curriculum for prospective teacher students in Malaysia. The results of the qualitative analysis of the interview data suggest that the predominant change of participants' personal satisfaction comes from the challenges of pro-environment behavior [4].

Holm (2017) in his research on climate change and human knowledge, revealed that exchanging knowledge and integrated platforms to channel humanities and social knowledge skills to study climate change might be a promising method [5]. The development of educational curriculum with green chemistry insights is one of the solutions. Important research is carried out in order to achieve the big goals of the global community who care about the environment in order to preserve the beloved earth, among others through green education [6]. Thus, a basic chemistry learning curriculum designed with green chemistry insight and its supporting devices was designed.

This article will present the results in a series of learning materials development with green chemistry insight. The issues to be addressed in this paper are; "How does the design of learning especially in basic chemistry to support a curriculum with green chemistry insight?". The purpose of this research is to describe the feasibility of curriculum design of Chemistry subject with green chemistry insights and its supporting device or learning materials.

\section{METHOD}

In principle, this method consists of three stages, namely: preliminary study stage supported by reference studies, material development phase, and evaluation phase by expert evaluation. Reference study had been done by mapping the concept or principles of green chemistry related to curriculum design of basic chemistry course that presented in the Semester Learning Plan (SLP). This phase identify the appear of green cemistry principles in learning. Development phase had been done by designing learning expereince with green chemistry insight for student that presented on SLP and Lesson Plan (LP). During the development phase, a limited trial was conducted which aimed to implement the learning plan based on green chemistry-designed curriculum. Product of development as a supporter of green chemistry curriculum in the form of draft validated by expert to get feasibility.

\section{RESULT AND DISCUSSION}

\section{A. Preliminary Study}

At this stage, needs assessment is conducted to analyze the urgency to develop a curriculum with green chemistry insight that supported by learning materials. Needs analysis is done by analyzing the existing documents in the Basic Chemistry course, especially available at the Department of Chemistry, State University of Surabaya. The analysis is done on the learning device document in the form of semester learning plan. The analysis had done to document of learning materials, like Semester Learning Plan (SLP), Student book, and Practical
Guidebook of Basic Chemistry. The result of analysis explained below.

1) Analysis of Semester Learning Plan (SLP) of Basic Chemistry Subject

The analysis had been done to SLP of Basic Chemistry that provided in this semester. Procedure of analysis focus on learning outcome, learning indicator, learning experiences, matter, strategy/model/method of learning. The result of analysis that related to green chemistry principles, in summary presented in Table 1.

Based on the SLP of Basic Chemistry course had have formula of learning outcome as follows:

a) Utilizing learning resources and ICTs to support the mastery of basic Chemistry concepts and theories.

b) Making decisions about the interconnection of basic concepts of chemistry with laboratory activities and the existence of chemistry in everyday life.

c) Have knowledge about the scientific method, material properties, stoichiometry, atomic structure, periodic system of elements, chemical bonding, energetic, and solution.

d) Have an honest and responsible attitude in conducting lectures and practicum.

Achievement of learning will be accommodated in the implementation of learning which is also a reference in the development of basic chemistry learning materials with green chemistry.

The description of the subject of Basic Chemistry is; Studies of basic concepts: Scientific Methods, Material Properties, Stoichiometry, Atomic Structures, Periodic System of Elements, Chemical Bonding, Energetic, Solutions, and appropriate laboratory activities through discussion, assignment, and practicum. With the formulation of learning achievements and description of the Basic Chemistry course, the competencies to be mastered by the students are:

a) Understanding chemistry as a result of scientific activities that study about matter with universal properties.

b) Understanding the things underlying stoichiometry, namely: basic laws of chemistry, atoms and molecules, the concept of moles and the constant of Avogadro, the formula of compounds, chemical reactions as well as the coincidence and equivalence

c) Understanding the development of basic atomic invention and particles according to Rutherford, Bohr, wave mechanics and electron configuration.

d) Understanding the development, usefulness, and basis of the preparation of the periodic system of elements, and its relation to the electron configuration of elements and the nature of the period.

e) Decide the linkage of the concept of chemical bonding and chemical forces to explain knowledge according to the course of study.

f) Understanding the terms of; laws of thermodynamics, and the determination of thermodynamic reactions. 
g) Understanding some aspects of the solution and apply it in terms of qualitative and quantitative, as well as application in daily life.

In the context of this study the competencies that must be attained by students are linked to the insight of green chemistry. Competence to be achieved is accomplished by providing an appropriate learning experience and supported by the suitable learning materials. Learning materials was expected to provide learning experiences to students by raising the principle of green chemistry on the material of the study. The result of SLP of Basic Chemistry course analysis based on Green chemistry is presented in Table 1 .

TABLE 1. DATA OF SUMMARY THE RESULT ANALYSIS OF SEMESTER LESSON PLAN OF BASIC CHEMISTRY COURSE

\begin{tabular}{|c|c|c|c|c|}
\hline No. & Study material & $\begin{array}{l}\text { Green Chemistry Principle } \\
\text { that can appear in learning }\end{array}$ & Learning Experience & $\begin{array}{c}\text { Learning } \\
\text { Strategy/Model / } \\
\text { Method }\end{array}$ \\
\hline 1 & $\begin{array}{c}\text { Introduction: } \\
\text { Stages of the scientific } \\
\text { method, Chemistry as a } \\
\text { scientific, material and } \\
\text { energy activity, extensive } \\
\text { and intensive properties, } \\
\text { chemical and physical } \\
\text { properties, elements, } \\
\text { compounds, and mixtures }\end{array}$ & $\begin{array}{c}\text { Principle nol. } \\
\text { Prevent / reduce the } \\
\text { formation of waste } \\
\text { Principle No. } 6 \\
\text { Energy efficiency } \\
\text { Principle No. } 5 \text { using solvent } \\
\text { and save chemicals } \\
\text { Principle No. } 12 . \\
\text { Prevent accident }\end{array}$ & $\begin{array}{l}\text { 1. Question and answer steps of scientific } \\
\text { method } \\
\text { 2. Provide examples of extensive and } \\
\text { intensive nature, } \\
\text { (create the classroom environment with } \\
\text { green chemistry insight by saving energy) } \\
\text { 3. Create concept maps and define the } \\
\text { nature of chemistry and physics, } \\
\text { elements, compounds, and mixture with } \\
\text { green chemistry insights (using limited } \\
\text { paper by writing on both side of paper) } \\
\text { 4. Conducting practicum of mixed separation } \\
\text { with green chemistry insights }\end{array}$ & $\begin{array}{l}\text { 1. Discussion (Think } \\
\text { Pair Share type) } \\
\text { 2. Question and } \\
\text { answer } \\
\text { 3. Learning strategy } \\
\text { of concept map } \\
\text { creation }\end{array}$ \\
\hline 2. & $\begin{array}{l}\text { Stoichiometry: Chemistry } \\
\text { Basic Law, Atoms and } \\
\text { molecules, Mol Concepts, } \\
\text { Avogadro Constants, } \\
\text { Compound Formulas, } \\
\text { Chemical Reactions and } \\
\text { Equivalence, Molarity and } \\
\text { Equivalence }\end{array}$ & $\begin{array}{c}\text { Principle no1. } \\
\text { Prevent / reduce the } \\
\text { formation of waste } \\
\text { Principle No. } 6 \\
\text { Energy efficiency } \\
\text { Principle No. } 5 \text { using solvent } \\
\text { and save chemicals } \\
\text { Principle no. } 12 . \\
\text { Prevent accident }\end{array}$ & $\begin{array}{l}\text { 1. Exercise to solve basic chemistry problems. } \\
\text { (create the classroom environment with } \\
\text { green chemistry insight by saving energy) } \\
\text { 2. Doing practicum Conservation of mass law } \\
\text { with green chemistry } \\
\text { 3. Conducting practicum chemistry reactions } \\
\text { with green chemistry } \\
\text { 4. Create concept maps of atoms and } \\
\text { molecules, as well as the mole concept. } \\
\text { 5. Practice on the Avogadro and Compound } \\
\text { Rules, } \\
\text { 6. Exercise on Chemical Reactions and } \\
\text { Equivalence, Molarity and Equivalence }\end{array}$ & $\begin{array}{l}\text { 1. Group discussion } \\
\text { 2. Doing Tasks } \\
\text { 3. Learning strategy } \\
\text { to create concept } \\
\text { maps } \\
\text { 4. Practicum }\end{array}$ \\
\hline
\end{tabular}

Learning experience like presented on Table 1, show that green chemistry insight can be implemented in classroom by creating class environment in saver energy condition, like using limited lights (Green Chemistry principle No.6), using limited paper by writing on both side of papaer to prevent or reduce the waste (Green Chemiatry principles No.1). So, in this case green chemistry principles appear related to the behavior or character.

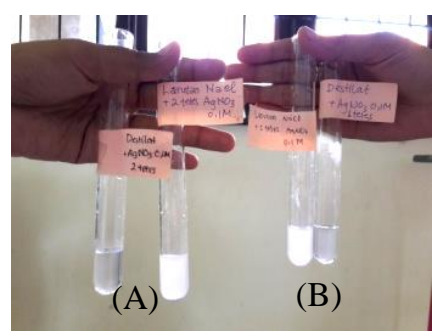

Fig. 1. The result of $\mathrm{Cl}^{-}$detection by adding $\mathrm{AgNO}_{3} \quad 0,1 \mathrm{M}$ (A) two drops (B) one drop
The test of distillation result by using $\mathrm{AgNO}_{3}$ agent to detect the presence of $\mathrm{Cl}^{-}$ion derived from $\mathrm{NaCl}$ that was added to the liquid in prior distillation process. The amount or volume of $\mathrm{AgNO}_{3} \quad 0.1 \mathrm{M}$ used for the test is reduced to half from two drops to one drop (its supported Green Chemistry principles No. 1 and No.6). By reducing number of droplets $\mathrm{AgNO}_{3}$ can still show the detection of the presence of $\mathrm{Cl}^{-}$ion in the solution before distillation process.

\section{B. Equations}

Feasibility of basic chemistry course design to support curriculum with green chemistry insight was evaluated by expert. Beside evaluate the curriculum design the experts also gave several feed back. Example of this feed back as presented in Table 2. 
TABLE 2 THE EXAMPLE OF THE RESULT IN EVALUATION PHASE BY EXPERT

\begin{tabular}{|c|c|c|c|}
\hline No. & Aspect & Feed back & Revision \\
\hline 1. & 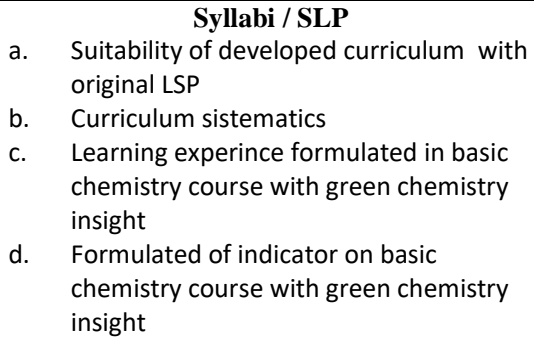 & $\begin{array}{c}\text { Expert 1: } \\
\text { Formulated a-d aspect were } \\
\text { suitable relatively, but need to } \\
\text { add green chemistry principles } \\
\text { more explicit. } \\
\text { Expert 2: } \\
\text { Developed LSP followed the } \\
\text { original document }\end{array}$ & $\begin{array}{l}\text { - It had been added learning } \\
\text { experiences/ learning activity with } \\
\text { green chemistry insight, but not change } \\
\text { indicator. } \\
\text { - Developed LSP matched to original LSP } \\
\text { and added the several green chemistry } \\
\text { principles that can be appeared in } \\
\text { learning }\end{array}$ \\
\hline
\end{tabular}

The validation results indicate that the average of the data often appear in very feasible categories. Thus, it can be said that the materials of basic chemistry course that developed is very feasible to be used in basic chemistry learning in order to support learning curriculum with green chemistry insight. The data from three validators that gave average value presented on Table 3.

TABLE 3. VALIDITY OF SUPPORTING MATERIALS OF BASIC CHEMISTRY CURRICULUM WITH GREEN CHEMISTRY INSIGHT

\begin{tabular}{|c|c|c|c|}
\hline No. & Aspect & $\begin{array}{c}\text { Percent } \\
\text { Average } \\
(\%)\end{array}$ & Category \\
\hline 1 & $\begin{array}{c}\text { Syllabi/Semester Learning Plan } \\
\text { (SLP) }\end{array}$ & 93,6 & $\begin{array}{c}\text { Very } \\
\text { feasible }\end{array}$ \\
\hline 2 & Lesson Plan & 97,3 & $\begin{array}{c}\text { Very } \\
\text { feasible }\end{array}$ \\
\hline \multirow[t]{4}{*}{3} & Student Worksheet (Theory) & & \\
\hline & $\begin{array}{l}\text { a. Criteria of Content } \\
\text { Feasibility } \\
\text { 1) Suitability of matter and } \\
\text { indicator }\end{array}$ & 100 & $\begin{array}{c}\text { Very } \\
\text { feasible }\end{array}$ \\
\hline & $\begin{array}{l}\text { 2) Suitability of desigh related } \\
\text { to green chemistry } \\
\text { principles }\end{array}$ & 88,6 & $\begin{array}{c}\text { Very } \\
\text { feasible }\end{array}$ \\
\hline & $\begin{array}{c}\text { b. Criteria of Prensentation of } \\
\text { Student worksheet }\end{array}$ & 91 & $\begin{array}{c}\text { Very } \\
\text { feasible }\end{array}$ \\
\hline \multirow[t]{4}{*}{4} & Student Worksheet (Practicum) & & \\
\hline & $\begin{array}{l}\text { a. Criteria of Content } \\
\text { Feasibility } \\
\text { 1) Suitability of matter and } \\
\text { indicator } \\
\end{array}$ & 98 & $\begin{array}{c}\text { Very } \\
\text { feasible }\end{array}$ \\
\hline & $\begin{array}{l}\text { 2) Suitability of desigh related to } \\
\text { green chemistry principles }\end{array}$ & 89,3 & $\begin{array}{c}\text { Very } \\
\text { feasible }\end{array}$ \\
\hline & $\begin{array}{c}\text { b. Criteria of Prensentation of } \\
\text { Student worksheet }\end{array}$ & 97 & $\begin{array}{c}\text { Very } \\
\text { feasible }\end{array}$ \\
\hline
\end{tabular}

Based on the data in Table 3 shown that the curriculum design of basic chemistry course with green chemistry insight very feasible with average value of validation of $93,6 \%$ of syllabi/SLP. The validation of supporting materials of Lesson plan is $97,3 \%$ on very feasible category. Feasibility of student worksheet both of theoretical and practice on very feasible category. The average percentage of theoretical student worksheet for the content feasibility of suitability with indicator aspect and correlation to green chemistry principles as well as presentation aspect respectively 100; 88,6; and
$91,0 \%$ on very feasible category. Practical student worksheet for this aspect respectively $98 ; 89,3$; and $97 \%$ on very feasible category.

Finding, students learning experiences of Basic Chemistry Course can be designed by integrating green chemistry principles to support curriculum design with green chemistry insight. Learning experience with green chemistry insight that can be implemented in classroom related to the behavior. For example create class environment in saver energy condition, like using limited lights (Green Chemistry principle No.6), using limited paper by writing on both side of paper to prevent or reduce the waste (Green Chemiatry principles No.1).

One example of implementation of green chemistry principle in laboratory activity by using little dose of substance that use in laboratory. Green chemistry principle No. 1 waste preventing or reducing can be apply by using little dose. Green chemistry principles can be integrated in both classroom learning activities or laboratory activities.

\section{CONCLUSION}

The results of this study showed that the principle of green chemistry can be raised as an insight on Basic Chemistry course both for classroom and laboratory learning. The green chemistry learning curriculum can bring green chemistry insight into the formulation of student's learning experiences. Among of 12 principles of green chemistry, the several principles that can be raised in the basic chemistry learning are; principle number 1) prevents or reduces waste generation, principle number 6) energy efficiency, and principle number 12, creates safer conditions and prevents accidents. The student's learning experiences are; question and answer about steps of scientific method, create concept maps, doing experiment in laboratory.

The feasibility of curriculum design of basic chemistry course with green chemistry insight very feasible with average value of validation of $93,6 \%$ of syllabi/SLP. The feasibility of supporting materials of Lesson plan is $97,3 \%$ on very feasible category. Feasibility of student worksheet both of theoretical and practice on very feasible category. The average percentage of theoretical student worksheet for the content feasibility of suitability with indicator aspect and correlation to green chemistry principles as well as presentation aspect respectively 
$100 ; 88,6$; and $91,0 \%$ on very feasible category. Practical student worksheet for this same aspect respectively $98 ; 89,3$; and $97 \%$ on very feasible category.

\section{ACKNOWLEDGMENT}

We would like to thank to Ministry of Research and Technology Directorate of Research and Community Service of Indonesian Government for financial support for all research for year 2017-2018. We also thank to Universitas Negeri Surabaya which gived facilities to do the research and publish this paper.

\section{REFERENCES}

[1] Mannahan, " Chemistry, green chemistry, and environmental chemistry. From green chemistry and the Ten Commandments of Sustainability", ChemChar Research, Inc., 2006 manahans@ @issouri.edu
[2] Drissner Jurgen, Haase Hans-Martun, Nikolajek Mara, and Hille Katrin, "Environmental Education in a Green Classroom", RESONANCE, February 2011.

[3] Karpudewan Margeswary, Ismail Zurida, and Roth Michael Wolt, "The Eficacy of Malaysia Pre-Service Teachers", International Journal of Science and Mathematicn Education (2012) 10, 2011, pp. 497-529.

[4] Karpudewan Margeswary, Ismail Zurida, and Roth Michael Wolt, "Fostering Pre-Service Teacher's Self-Determined Environmental Motivation Through Green Chemistry Experiments", J. Science Teacher Educ (2012) 23, 2012, pp. 673-696

[5] Holm P. and Winiwarter V, "Climate change studies and the human sciences", Global and Planetary Change, Available online 22 May 2017. http://www.sciencedirect.com/science/article/pii/S092181811630306X. acessed 25 July 2017.

[6] Ekasari Nurbaiti, "Selamatkan Bumi Dengan Green Education", Sumatera Express, 2008,

http://nurbaiti-ekasari.blogspot.com/2010/12/selamatkan-bumi-dengangreen-education.html accesed 22 April 2013 